\title{
GEOMORPHOLOGICAL CONDITIONS OF THE GENESIS OF THE PONOR JOVAC CAVE (CROATIA)
}

\author{
GEOMORFOLOŠKE OKOLIŠČINE NASTANKA JAME \\ PONOR JOVAC (HRVAŠKA) \\ NEVEN BOČIĆ ${ }^{1} \&$ ŽELJKO BAĆURIN ${ }^{2}$
}

\footnotetext{
${ }^{1}$ Department of Geography, Faculty of Science, Maruliceev trg 19/II , 10000 Zagreb, Croatia, e-mail: nbocic@geog.pmf.hr

${ }^{2}$ Speleological society Karlovac, Strossmayerov trg 8, 47000 Karlovac, Croatia
} 


\begin{abstract}
UDC: 551.44(497.5)

Neven Bočić \& Željko Baćurin: Geomorphological Conditions of the Genesis of the Ponor Jovac Cave (Croatia)
\end{abstract}

The middle part of the Slunj karst plateau is built of permeable karstified upper Cretaceous limestone. The Miocene sandstones and marls lie over them in transgressive contact in the form of denudation remains. This area is impermeable and has characteristics of fluviodenudational relief. In a morphological sense, the blind valley of Đedinovac periodical stream is remarkable. The Đedinovac stream sinks underground in the contact zone of the Miocene and Cretaceous rocks and continues its flow through the main channel of the Ponor Jovac cave. The Ponor Jovac cave is $689 \mathrm{~m}$ long and has the function of a permanent percolating and periodical sinkhole cave. The area built of limestone is well karstified and without a surface fluvial network. But in continuation of the Đedinovac stream blind valley a dry valley exists which is a morphological trace of the former surface flow of the Đedinovac stream

Key Words: speleology, karst geomorphology, Ponor Jovac cave, Slunj plateau, Croatia.

Izvleček

UDK:551.44(497.5)

\title{
Neven Bočić \& Željko Baćurin: Geomorfološke okoliščine nastanka jame Ponor Jovac (Hrvaška)
}

Osrednji del slunjske kraške planote gradi prepustni zakraseli gornjekredni apnenec. Na njem leže v transgresijskem stiku denudacijski ostanki miocenskih peščenjakov in laporjev. Ta del površja je neprepusten z značilnostmi fluviodenudacijskega reliefa. Z morfološkega vidika je pomembna slepa dolina ponikalnice Džedinovac. Potok ponika na stiku miocenskih in krednih kamnin in teče dalje po glavnem jamskem rovu Ponora Jovac. Jama je dolga $689 \mathrm{~m}$ in je stalna pretočna oziroma občasna ponorna jama. Svet na apnencu je dobro zakrasel in brez površinske rečne mreže. Pač pa se slepa dolina Džedinovac nadaljuje s suho dolino, ki je morfološka sled nekdanjega površinskega toka potoka Džedinovac.

Ključne besede: speleologija, kraška geomorfologija, Ponor Jovac, slunjska planota, Hrvaška. 


\section{INTRODUCTION}

The Cave Ponor Jovac is located $13 \mathrm{~km}$ south-east of the town of Slunj, i.e. about $16 \mathrm{~km}$ north-east of the National Park Plitvice Lakes in Croatia. According to the geomorphological classification of Croatia (Bognar 2001), this area belongs to subgeomorphological region 2.1.6.1.: Slunj plateau with Rakovica hills, i.e. mezogeomorphological region 2.1.6.: the Una - Korana plateau with south-west Kordun hills; macrogeomorphological region 2.1.: Mountainous Croatia, and megageomorphological region 2: the Dinaric mountains system.

The subgeomorphological region of the Slunj plateau and Rakovica hills can be divided into microgeomorphological regions: 2.1.6.1. Slunj plateau and 2.1.6.2. Rakovica hills. The cave Ponor Jovac is located in the central part of the Slunj plateau. The Slunj plateau is, hydrologically speaking, a part of the shallow Dinaric karst of Croatia (Herak et al. 1969), i.e. its eastern part and, geotectonically speaking, it is the north-east part of the Dinaric structural complex (Herak 1986). It spreads from the furthest western part of the Una River towards north-west, reaching the place where the Slunjčica flows into the Korana at an average height of 300-350 m, for a length of about $40 \mathrm{~km}$, on average $10 \mathrm{~km}$ wide.

The creation of the karst plateaus was dealt with in 1951 by Roglic (1957), and with special emphasis on the Una-Korana plateau. In his works, he accentuates the corrosion processes on limestone as the major process of the flattening of the relief. The question of karst plateaus is further investigated by Bahun (1990) who accentuates the abrasion processes with the finishing corrosion modeling, as well as the influence of neotectonics. Bognar (1994) investigated the processes of the flattening of the Dinaric relief and gave an explanation of the creation of the plateau. Unlike previous investigators he accentuates the slope processes which result in the flattening of the relief. In this sense the area of Slunj plateau is a partially disturbed fragment of an older level of flattening. The relationship between surface geomorphological processes and the process of speleogenesis with examples of Slunj plateau are presented by Bočić (2003).

Speleological explorations of this area have been conducted since the $19^{\text {th }}$ century. Up to now over a hundred caves have been found, some longer than one kilometer and with one huge cave system over $12 \mathrm{~km}$ long. In bibliographies the cave Ponor Jovac is mentioned within the framework of hydrogeological basis for the speleogenesis of the cave system Panjkov ponor - Varićakova cave (Čepelak 1983; Garašić 1991). Cave Ponor Jovac was systematically explored and surveyed (Fig. 1) by a team of the Speleological Society Karlovac and the Department of Geography of Faculty of Science between 2002 and 2004. The cave exploration was made by: I. Abramović, K. Abramović, Ž. Baćurin, N. Bočić, S. Pjevac and P. Rade.

\section{GEOLOGICAL AND GEOMORPHOLOGICAL SETTINGS}

The cave Ponor Jovac is located in the central part of the Slunj plateau. Slunj plateau is made of permeable and karstified limestone of the upper Cretaceous and impermeable clastites (sandstone, clay) of the Miocene (Korolija et al. 1979, 1981). Miocene sediments lie over Cretaceous limestone in a transgressive contact. Today they represent denudation remains on which the surface fluvial network developed. On this part fluviodenudation processes of the relief formation are noticeable, and the most developed surface formations are valleys. At the line of contact between clastites and 


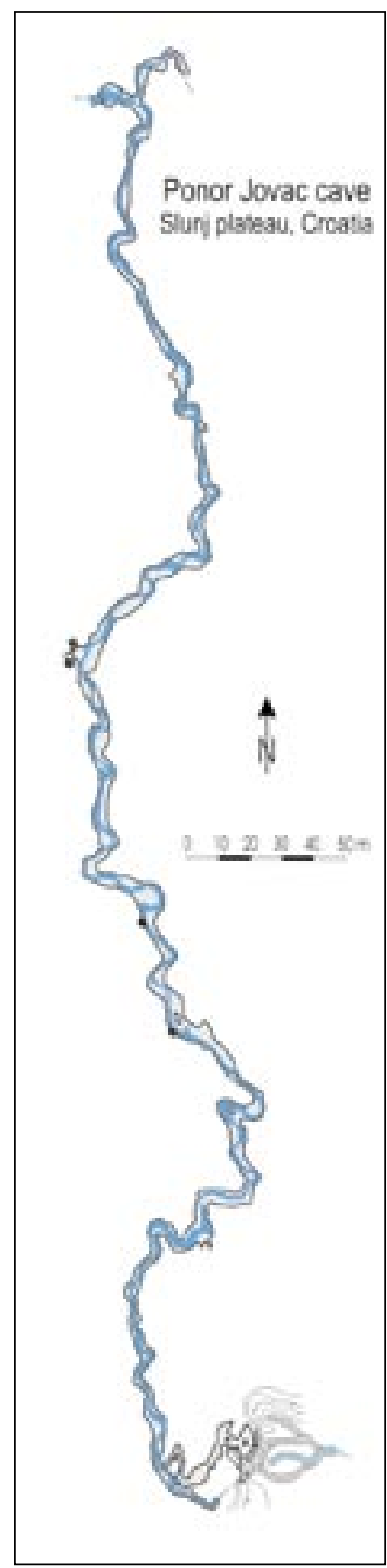

Fig. 1: Plan of Ponor Jovac cave (surveyed by Ž. Baćurin and $N$. Bočić). limestone there is sinking underground, so active parts of the valleys were reshaped into blind valleys (Fig. 2). The continuation of these valleys can be seen in the area made of limestone. This part of the valleys are dry and usually well karstified. They represent traces of the former surface fluvial network.

Đedinovac stream flows through the valley north-eastward on the area made of Miocene clastites. It sinks through alluvial layers in front of the entrance to cave Ponor Jovac in the zone of contact with Cretaceous limestone. This water appears about 50 $\mathrm{m}$ further down in the cave. The cave is $689 \mathrm{~m}$ long, and has the function of a sinking and percolating cave. The continuation of the blind valley of Đedinovac stream is seen in the form of a dry valley which is a morphological trace of the former surface flow of Đedinovac stream. The dry valley is about $300 \mathrm{~m}$ long northeastwards, then $1,5 \mathrm{~km}$ south-eastward, where it connects with the active valley of Perlinac stream which sinks underground in Panjkov ponor (Čepelak 1983; Garašić 1991; Bočić 2003). Contrary to expectations that the cave canals of Ponor Jovac spread eastwards (in the direction of the dry valley through which Đedinovac stream once flowed on the surface), the cave - in its explored part (close to $700 \mathrm{~m}$ ) - extends northwards.

\section{CAVE MORPHOLOGY}

The known and explored part of the cave Ponor Jovac (Fig. 1) is a simple conduit of the total length of $689 \mathrm{~m}$. The cave is made in upper Cretaceous limestone, but in the first part carbonate breccia (probably in transgressive position), were detected. Most of the cave channels are partially flooded which makes moving through the cave hard. In terms of morphology, the cave consists of three parts. The first part is approximately 200 $m$ in length from the entrance. It starts with a well-developed anastomotic morphology (Palmer 2001) and after $100 \mathrm{~m}$ takes on a simple «one-channel» morphology. The average width of the channel in this part is about $2 \mathrm{~m}$, and height $1.5 \mathrm{~m}$. In this part there is also one periodical sump, and the bottom is filled with sand and mud (especially in the sump zone). This part of the cave is made in carbonated breccia and it is assumed that this is the youngest part of the cave. Due to this, the channels are narrower here than anywhere else. The second part of the cave extends between 200 and $470 \mathrm{~m}$ of its length. It consists of the main channel only, with an average width of 4-5 m, and height $3-5 \mathrm{~m}$. In this part of the cave the meander morphology is 
most prominent, and even more so the meandering of the water flow in the channel. Meander niches developed in the crowns (Slabe 1995, Lauritzen \& Lundberg 2000). On the basis of this morphology is can be concluded that in this part of the cave neotectonic rising was most intensive. The third part of the cave is from $470 \mathrm{~m}$ to the end of the cave. The average width and height of the channel are slightly less than the central $\left(2^{\text {nd }}\right)$ part. Meandering is less strong, and the channel is much straighter. There is also a periodical sump present there. The sediments in the channel are sand and mud, as in the first part. The cave ends with permanent downstream sump which has not been passed yet. In this part of the cave relative neotectonic lowering is probably present, i.e. the relative rising of the lesser intensity than in the central part of the cave. The overall spreading of the cave is northwards, unlike the dry valley on the surface which first runs north-eastward, and then south-eastward. Further explorations will show whether the subterranean water flow keeps heading north, or changes as well. The greatest part of the channels in the cave has the so-called canyon morphology which indicates a dominant development of the channel in vadose conditions. In this cave, the channel's meandering index is 1,33 (in the lower part of profile), and the meandering of the recent subterranean flow (on the bottom of the channel ) is 1,52. It also indicates greater quantities of water in the past than today (Lauritzen \& Lundberg 2000).

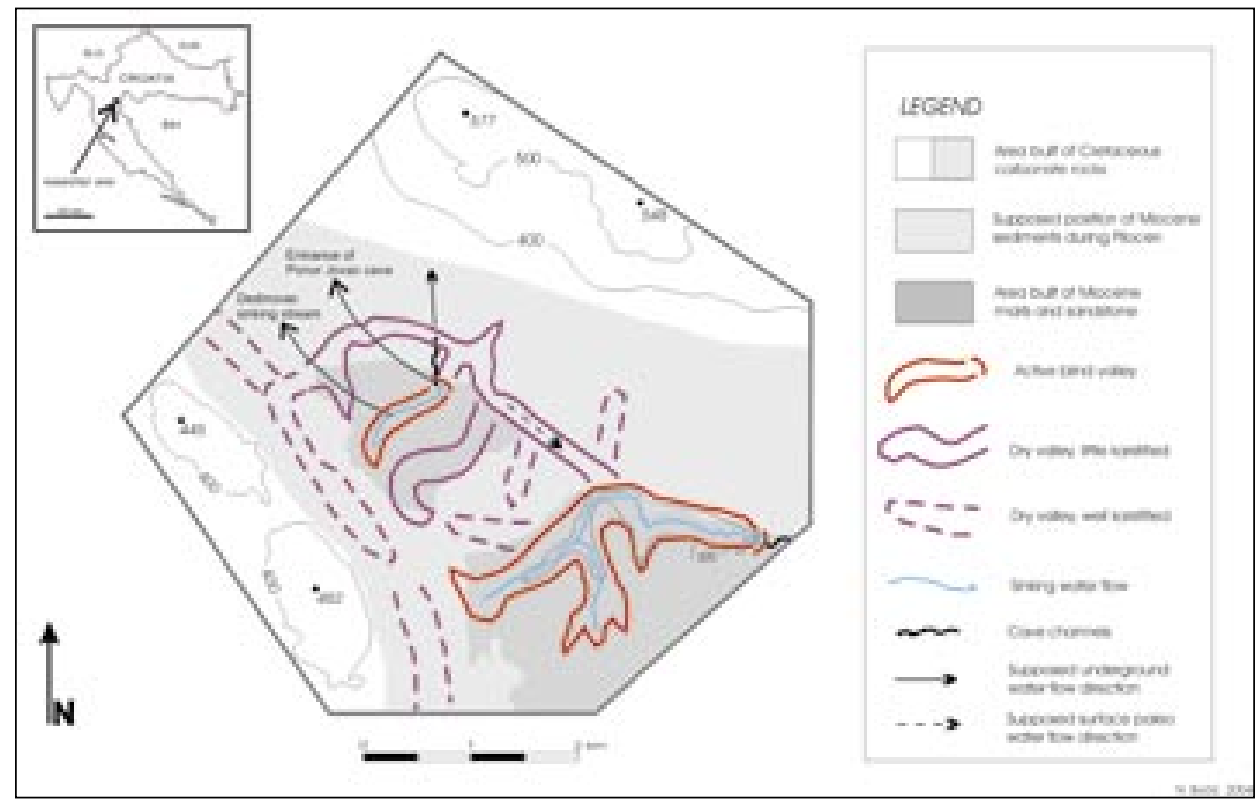

Fig. 2: Geomorphological sketch of area of Ponor Jovac cave in the middle part of the Slunj karst plateau (Croatia). 


\section{CONCLUSION}

The conditions for the genesis and development of the cave Ponor Jovac were created on the contact between the clastic Miocene layers and permeable upper Cretaceous limestone (Fig. 2). These conditions are characteristic for contact karst (Gams 1986). Miocene layers were spread over a much greater area. Thanks to their impermeability the surface fluvial network developed. Through the clastite denudation their surface lessened, and carbonate layers of the upper Cretaceous surfaced, being then subjected to the karst process. The surface fluvial network was retained only in the areas where the denudation of Miocene clastites remains. The valley of the Đedinovac stream developed as the consequence of the fluviodenudation processes, i.e. the carving in of Đedinovac stream. Đedinovac stream flowed on the surface for over $3 \mathrm{~km}$, first north-eastward, then south-eastward and was probably a left tributary of the Perlinac stream. The location of the zone of contact between clastites and limestone changed due to denudation (the surface covered by classical layers lessened) and it cut the Đedinovac valley. Underground sinking of the stream occurred, turning it into an allogenic water flow and changing the surface relief. The active part of the valley was transformed into a blind valley ending with a ponor, while the dry part of the valley was partially karstified. The underground part of Đedinovac stream and its corrosive and erosive work shaped the underground channels (Ford \& Williams 1994) of the cave Ponor Jovac which spreads northward in its explored part. The main morphological characteristic of the cave is a simple morphological type with marked meandering of the main channel and its flow. On the crowns of the meander deep corrosive niches developed - meandering niches (Slabe 1995, Lauritzen \& Lundberg 2000). This kind of meandering of a cave channel is most likely a consequence of neotectonic uplifting of a tectonic block, as confirmed in the neighbouring Varićakova cave by Garašić (1991). It is especially marked in the central part of the cave. There was no dating of the cave sediment so the age of the cave cannot be reliably determined. However, based on the comparative morphological characteristics it can be concluded that it is younger than the cave system Panjkov ponor -Varićakova cave, whose genesis, according to Garašić (1984) started in the Neogene. 


\section{REFERENCES}

Bahun, S., 1990: Stupnjevi razvoja zaravni u kršu. Krš Jugoslavije 12/6, 147-158, JAZU, Zagreb

Bočić, N., 2003: Relation between karst and fluviokarst relief on the Slunj plateau (Croatia). Acta carsologica, 32/2, 137-146, Ljubljana

Bognar, A., 1994: Neke od temeljnih značajki razvoja pedimenata u gorskoj zoni vanjskih Dinarida. Geografski glasnik 56, 21-31, Hrvatsko geografsko društvo, Zagreb

Bognar, A., 2001: Geomorfološka regionalizacija Hrvatske. Acta Geographica Croatica 34, 7-29, Geografski odsjek PMF-a, Zagreb

Čepelak, M., 1983: Špiljski sustav Panjkov ponor - Kršlje. Speleolog 30/31, 21-27

Ford, D. \& Williams, P., 1994: Karst Geomorphology and Hydrology. Chapman and Hall, London Gams, I., 1986: Kontaktni fliviokras. Acta carsologica 14 -15, 71-87

Garašić, M., 1984: Neotektonske aktivnosti kao jedan od uzroka geneze i morfologije jednog od najvecih spiljskih sistema u Hrvatskoj. 9. jugosl. speleološki kongres, Zbornik radova, SDH, 457-465, Karlovac

Garašić, M., 1991: Karstifikacija spiljskog kanala iza Zelenog sifona i njegova hidrogeološka uloga u spiljskom sustavu Muškinje i Panjkove špilje na Kordunu. Spelaeologia Croatica 2, 5-14, Zagreb

Herak, M., Bahun, S. Magdalenić, A., 1969: Pozitivni i negativni utjecaj na razvoj krša u Hrvatskoj. Krš Jugoslavije 6, 45-71, JAZU, Zagreb

Herak, M., 1986: A new concept of geotectonics of the Dinarides. Acta Geologica 16/1, 1-42, Zagreb

Korolija, B., Živaljević T. \& Šimunić, A., 1979: Osnovna geološka karta 1: 100000 list Slunj. Savezni geološki zavod, Beograd

Korolija, B., Živaljevic T. \& Šimunić, A., 1981: Tumač Osnovne geološke karte 1: 100000 za list Slunj. Institut za geološka istraživanja, Zagreb

Lauritzen, S. E. \& Lundberg, J., 2000: Solutional and erosional morphology. In: Speleogenesis, Evolutions of Karst Aquifers, ed: Klimchouk, A. et. al., 408 - 426, NSS, Huntsville

Palmer, A. N., 2001: Dynamics of Cave Development by Allogenic Water. Acta carsologica Vol. 30, 13-32

Roglić, J., 1951: Unsko - koranska zaravan i Plitvička jezera - geomorfološka promatranja. Geografski glasnik 13, 49-68, Hrvatsko geografsko društvo, Zagreb

Roglić, J., 1957: Zaravni na vapnencima. Geografski glasnik 19, 103-131, Hrvatsko geografsko društvo, Zagreb

Slabe, T., 1995: Cave Rocky Relief and its Speleogenetical Significance. Založba ZRC SAZU, 10, 128 pp., Ljubljana 
